\title{
Pressure Analysis on the Surface Gearing Investigated by Numerical Simulation of Oil Flow in the Tooth Wheel Gap
}

Stanislav Jirouš, Karel Fraňa

Department of Power Engineering Equipment, Technical University of Liberec. Studentská 2, 461 17, Liberec. Czech Republic.E-mail: stanislav.jirous@gmail.com,karel.frana@tul.cz

The key topic of this article is a study of the oil flow and pressure distribution on the surface gearing investigated using numerical simulations. Particularly, this paper is focused on a simulation of the single flow of oil, which is governed by the gearing motion. Results of the unsteady flow between two rotating gearing could help to identify reasons of damages of gearings. The destruction of surface is identified after several hours on the helical gearing which is used in a heavy industry. In the case of moving and rotating gearing, it was necessary to use dynamic mesh and procedure of remeshing based on the parameters of quality cells. The simulation provides the complete information of pressure distribution on the surface of gearings. By the analysis of numerical results the areas with the high frequencies of low pressure were identified.

Keywords: Computational fluid dynamic, dynamic mesh, oil flow, cavitations

\section{Acknowledgement}

This work has been financially supported by the research project TUL No. SGS 21000.

\section{References}

[1] BRENNEN, C.E. (1995). Cavitation and Bubble Dynamics, Oxford University Press.

[2] FERZIGER, J. H., PETRIC M. (1999). Computional methods for fluid dynamic,2nd edition, Springer Verlag.

[3] Fluent Documentation, www.Ansys.com/Support/Documentation

[4] JIROUŠ, S. (2008). Numerická simulace toku oleje v mezeře ozubených kol, diplomová práce, Technická Univerzita v Liberci, 2008.

[5] LEMFELD, F., FRAŇA, K., UNGER, J. (2008). Numerical simulations of unsteady oil flows in the gear-boxes. Journal of Applied Science in the Thermodynamics and Fluid Mechanics, Liberec, Czech republic, 1/2008, pp. 2732, ISSN 1802-9388

[6] Paramo a.s., Katalog produktů, www.eshop.paramo.cz

[7] SKOČILASOVÁ, B., SKOČILAS, J. (2013). Simulation of liquid flow in pipe. In: Manufacturing Technology, ISBN 1211-4162

[8] WUSTMANN, W., HELDUSER, S. (2008). CFD-Simulation of the Reversing Process in External Gear Pumps. ANSYS Conference \& 26th CADFEM Users Meeting. 